\title{
Changing patterns in the organization of the venereal diseases and treponematoses service in Uganda
}

\author{
O. P. ARYA \\ Department of Preventive Medicine, Makerere University Medical School, Kampala, Uganda
}

\begin{abstract}
Uganda, which is primarily an agricultural and pastoral country, forms a beautiful part of the main plateau of East Africa. It is bordered by Kenya on the east, Congo and Rwanda on the west, Southern Sudan on the north, and Tanzania and Lake Victoria on the south. Its four regions-Central (Buganda), Eastern, Western, and Northernroughly correspond with an ethnic complex. The northern region has largely Nilotic and Sudanic people, the eastern region Bantu and Nilo-Hamitic people, and the western and central regions have Bantu-speaking peoples. Each region has four to six districts, most of which have ethnic populations with distinct cultural characteristics such as diet and living habits. Polygamy is not uncommon. There are also important African immigrant communities from neighbouring countries who account for over 5 per cent. of Uganda's population of 9.54 millions (Uganda, 1971, 1972). Over 90 per cent. of the population live in rural areas and 46 per cent. are below the age of 15 .
\end{abstract}

\section{The V.D. services}

THE PAST

Venereal disease in almost all its forms has been common in Uganda, as indicated by the earliest medical observations made about a century ago (Foster, 1970). The Annual Medical Reports of the Uganda Ministry of Health from the earlier part of the 20th century support this; Keane (Uganda, 1921) estimated that about 80 per cent. of the native population had suffered or was suffering from venereal disease in one form or another. This figure appears excessively high; it is probable that the diagnosis of venereal and congenital syphilis was overused (Davis, 1956; Muwazi, Trowell, and Davies, 1947). Nevertheless, venereal disease played an important role in the organization of the medical services in Uganda in the beginning of this century. So rampant were these diseases at the time that the chiefs were 'deeply concerned with regard to the future of their population' in some parts of Uganda
(Uganda, 1913). Syphilis was then declared to be a dangerous disease under the Dangerous Diseases Ordinance (Uganda, 1912). Compulsory legislative measures for the control of venereal diseases were prepared, only to be allowed to lapse within a few years because there were too many defaulters and too few staff. However, this concern for venereal disease led to the building of a special hospital in 1912-13 in Kampala for the treatment of venereal diseases; this was later to become the national reference hospital-now called Mulago Hospital. Within a few years more V.D. treatment centres run by trained indigenous clinical assistants were opened. These centres formed the basis of the future expansion of the general medical services in some parts of Uganda in the 1920s. No sooner had this happened than it became clear that there were several other important health problems meriting similar consideration. Venereal diseases thereafter could no longer claim a special position in respect of money or staff.

The story of 'syphilis' in Uganda is of considerable interest and has been expertly dealt with by Davies (1956). Here it need only be mentioned that in Uganda treponematoses other than venereal syphilis seem to have disappeared. (The author has seen only one case of early yaws in a young child during the last 14 years in Uganda.)

\section{THE PRESENT}

It is not possible to describe the present V.D. services in isolation. In fact, there are no special V.D. services in Uganda except in the biggest hospital. To understand how and where these services are provided it is necessary to describe briefly the relevant parts of the organization of health services in Uganda.

Uganda is a poor country, in fact one of the 25 'hard-core' least developed countries on the U.N. list (United Nations, 1971). The overall doctor : population ratio is $1: 16,000$, and much worse than that in many rural areas. The situation regarding 
some other categories of health staff is equally unfavourable. The health expenditure in Uganda until recently was approximately 7 Uganda shillings per head per year, i.e. approximately 1 U.S. dollar (King, 1966). It is now just over 10/- per head (the recurrent expenditure) and little change is expected over the next 5 years (Uganda, 1972).

No reliable figures on the incidence of venereal diseases throughout the country are yet available because of the lack of diagnostic facilities and adequately trained staff. But there is evidence that almost all types of sexually transmitted diseases, uncomplicated and complicated, are very common. Over 25 per cent. of the male university students report with a venereal disease of one form or another every year (Arya and Bennett, 1967). 16,000 cases of gonorrhoea, 2,000 cases of early syphilis, and thirty cases of early congenital syphilis (under 1 year) were seen in the V.D. clinic of Mulago Hospital, Kampala, in 1971 (Lomholt, 1972) as compared with 1,606 cases of early syphilis and sixteen of early congenital syphilis in the whole of England in 1971 (Department of Health and Social Security, 1972). In some areas of Uganda almost 30 to 50 per cent. of women are sterile by the age of 30 , allegedly through gonorrhoea (Griffith, 1963). In males, 389 new cases of urethral stricture were seen and about 250 men were admitted to the Mulago Hospital in the year 1971 (Obonyo, 1972). Gonococcal ophthalmia neonatorum is not uncommon. In recent surveys in two rural areas gonorrhoea prevalence rates of 1.12 per cent. and 7.4 per cent. were found after a single examination (Arya and others, in preparation, 1972). Another rural area had incidence rates of $2 \cdot 76$ per cent. for gonorrhoea and 0.5 per cent. for early syphilis in 1971 (Ongom, Lwanga, Mugisha, and Mafigiri, 1971). Table I shows estimated gonorrhoea rates as compared with some other parts of the world. Cases of cardiovascular syphilis

TABLE I Gonorrhoea case rates per 100,000 population

\begin{tabular}{|c|c|c|}
\hline Country & 1970 & 1971 \\
\hline $\begin{array}{l}\text { Sweden } \\
\text { Denmark } \\
\text { U.S.A. } \\
\text { Atlanta, Ga. }\end{array}$ & $\begin{array}{l}485^{\mathrm{a}} \\
300^{\mathrm{a}} \\
285^{\circ} 2^{\mathrm{b}} \\
\left(900 \text { estimated }^{\mathrm{a}}\right) \\
2474^{\mathrm{b}}\end{array}$ & \\
\hline \multicolumn{3}{|c|}{ Estimated rates in some parts of Uganda } \\
\hline $\begin{array}{l}\text { Kampala (urban) } \\
\text { Teso (rural) } \\
\text { Kasangati (semi-rural) } \\
\text { Ankole (rural) }\end{array}$ & & $\begin{array}{r}15,000 \\
7,500 \\
2,760 \\
1,200\end{array}$ \\
\hline
\end{tabular}

are not infrequently seen in the Mulago Hospital Cardiac Clinic as well as at necropsy (Somers, 1972). In 1969-70, there were 34 new cases of neurosyphilis (mostly G.P.I.) admitted to Butabika Mental Hospital, Kampala (Masawe and German, 1971). Nongonococcal urethritis is also commonly seen (Arya, 1972a). Among other sexually transmitted diseases, chancroid and trichomoniasis are particularly common. The existing ecological milieu, comprising prostitution, migrant labour, rapid urban growth, and other contributory socio-economic factors will continue to foster these trends.

Uganda now has a reasonable network of health services throughout the country as compared with some other countries in Africa. These are mainly provided by the Government and are organized on a regional and district basis-hospitals being situated in the main towns while health centres, dispensaries, and aid posts"serve the rural areas. Table II shows the scheme of health organization in Uganda. All the basic health services provided by the Government are free of charge. Private practitioners are concentrated in the main towns. There are also some missionary medical units and a few provided by industry.

TABLE II Organization of government health services in Uganda

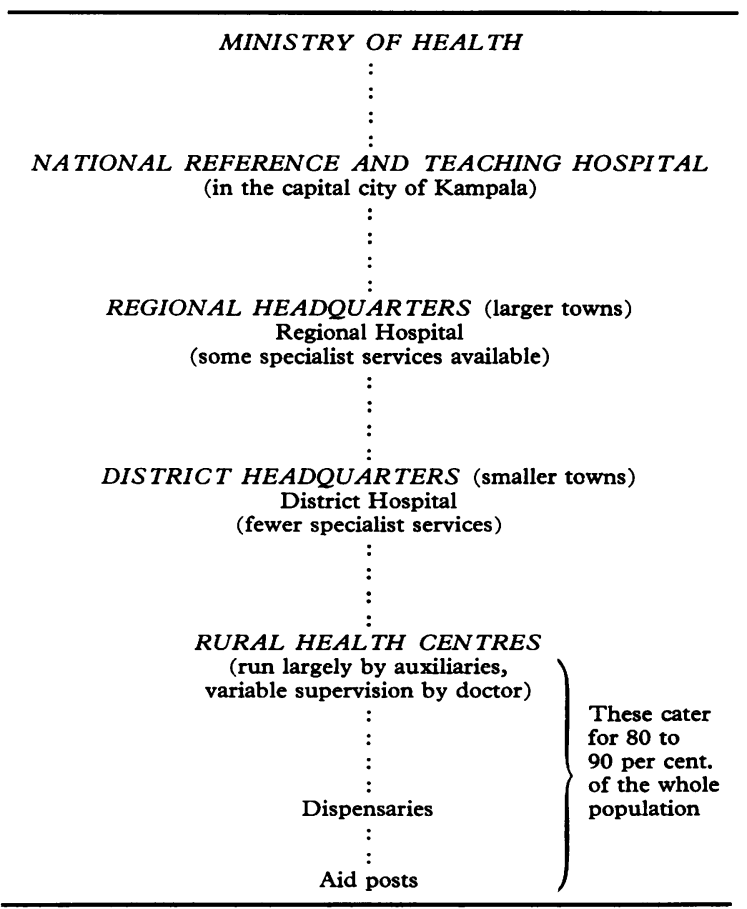


Rural health centres and dispensaries form the backbone of the health services catering for over 90 per cent. of the population. These are often understaffed with mostly well-trained general duty medical auxiliaries, but laboratory facilities and supplies of appropriate drugs are inadequate.

Venereal disease is diagnosed and treated in all the medical units mentioned above, mostly on an outpatient basis by auxiliaries with no special training in the subject. An unknown amount of venereal disease is also being treated by the patients themselves, e.g. by 'capsules' purchased on the black market, or by quacks in the rural areas. Screening programmes are limited to occasional research projects; such an undertaking on a routine basis would be an impossible task in most busy clinics.

On the credit side some important developments in the venereal disease services have taken place in Uganda in recent years. These include a re-awakening of interest and a beginning of the recognition of the problem, the establishment of a few centres on a scientific basis, and the appointment of a specialist dermatovenereologist in the Mulago Hospital, Kampala. Some useful research carried out in these centres includes the clinical pattern of venereal disease; antibiotic sensitivity of gonococci (Phillips, Fernandes, Pirani and Wagaine, 1969; Arya and Phillips, 1970); evaluation of treatment schedules (Arya and Phillips, 1970; Arya, Pearson, Rao, and Blowers, 1970; Arya, Rao, and Nnochiri, 1971; Arya and Bosa, 1972; Masawe, Nsibambi, and Lomholt, 1972); behavioural studies (Arya and Bennett, 1968; Bennett, 1962, 1964); serological studies (Foster and Kerchan, 1966; Masawe, 1970); and health education in venereal disease (Arya, 1972b). A venereal disease laboratory in the Makerere University Medical School, Kampala, has been completed, and medical students are now receiving fairly adequate training in all sexually transmitted diseases. In short, Uganda is now going through a period of 'renaissance' in the campaign against venereal disease.

\section{THE FUTURE}

The manpower problem with the present rate of population growth shows little promise of significant improvement in the doctor : population ratio in the near future. This, coupled with economic restraints, implies continued reliance on health centres staffed by medical auxiliaries. The fact that the present methods of venereal disease control (unless very vigorously applied) have failed to produce any significant and lasting impact in most of the developed and rich countries could hardly encourage the poor countries to spend their limited resources on the losing battle against V.D., especially when there are several other serious problems which have been given a higher priority in Uganda. These include malnutrition, killing diseases, such as malaria, tuberculosis, and other communicable diseases, maternity and child health services, and environmental sanitation: all of these need men, money, and materials. However, venereal diseases must come very high in the morbidity list and possibly should rate among the higher priorities. This might at the same time require special consideration to be given to the problem of population growth, especially, as already mentioned, because of the high incidence of sterility considered to be due to gonorrhoea.

Considering these circumstances, one may attempt to project the development of the V.D. services in the foreseeable future. Specialist and all but simple laboratory services will continue to be confined to the capital city of Kampala for some time to come. The bulk of venereal disease patients in the rest of the country will continue to be seen by auxiliaries in the district hospitals and the rural medical units with variable amounts of supervision by doctors within the existing framework. The scope of auxiliaries and rural health centres in the developing countries has been admirably discussed by Maurice King (1966). The Uganda Government is committed to the provision of a rural health centre in each of the country's 614 districts (Uganda, 1972) as an ultimate goal. Such health centres are particularly suited to the problem of communicable disease control, including venereal disease, because of the kind of staff they have and the emphasis on community activity (including health education and contact tracing). Venereal disease services in health centres and district hospitals can be improved by putting appropriate emphasis on the subject in the curriculum for the training of medical auxiliaries (e.g. medical assistants, health assistants, and other nursing-aids in Uganda) who run the health centres and out-patients departments of the hospitals. To this may be added the training of polyvalent microscopists (including simple diagnostic procedures for the venereal diseases) based on a course similar to the one compiled by Heinze and Galea (1971); at least one such microscopist could be stationed in every health centre.

In the district hospitals and in larger towns-the latter having health centres and public clinics provided by the town councils-there is scope for full-time specially trained V.D. auxiliaries. There is a real possibility of setting up facilities to train these V.D. auxiliaries as well as giving postgraduate training in V.D. for doctors in the near future.

Another important facet of the problem is the role 
of private practitioners in the control of venereal disease in Uganda. They are likely to continue to form the backbone of general curative services in the larger towns for some time to come. It is not known exactly how many cases of venereal disease are treated by them, but there is some evidence that it forms a considerable proportion. The quality of this service is also not known; laboratory facilities are lacking and there is an almost total absence of contact tracing. Without adequate free laboratory and epidemiological services there is little possibility of any significant improvement in the private practitioners' contribution to venereal disease control apart from keeping them informed of the appropriate treatment practices relevant to this country.

In conclusion then, unless the diagnostic and treatment facilities can be improved for the whole country including the rural areas, no meaningful progress in venereal disease control can be made at the present time. Above all it must be understood that the development of a good health service is tied up with the economic development of the country, and that this is the most important decisive factor. 'The main determinant of the pattern of medical care in developing countries is poverty, rather than a warm climate.' (King, 1966).

\section{Summary}

The organization of medical services in Uganda began at the beginning of the 20th century. In some parts of Uganda these facilities were started mainly to treat venereal diseases and this formed the basis of future expansion of the general medical services.

No reliable figures about the incidence of venereal diseases throughout the country are available, but there is evidence that almost all types of sexually transmitted disease are very common.

Uganda now has a fairly widespread network of rural health centres and dispensaries staffed by medical auxiliaries which cater for about 90 per cent. of the population. Scientific venereal disease services are available in only a few centres where nevertheless some useful research has been carried out.

There are several problems more important than venereal diseases which need men, money, and materials. The possibilities for improvement in the V.D. services within the existing framework are discussed, and it is suggested that venereal disease should be given a higher priority as a health problem.

I am grateful to Prof. F. J. Bennett and Dr. G. Lomholt for their helpful comments.

\section{References}

ARYA, O. P. (1972a) E. Afr. med. F., 49, 817

(1972b) Health education in venereal disease. Awaiting publication

and BENNETT, F. J. (1967) Brit. F. vener. Dis., 43, 275 (1968) Ibid., 44, 160

and Bosa, C. B. (1972) Uganda med. F., 1, 122

, Pearson, C. H., RaO, S. K. and Blowers, R. (1970)

Brit. F. vener. Dis., 46, 214

and Phillips, I. (1970) Ibid., 46, 149

-, RAO, S. K., and NNOCHIRI, E. (1971) Ibid., 47, 184

BENNETT, F. J. (1962) E. Afr. med. f., 39, 332

(1964) Ibid., 41, 163

Davies, J. N. P. (1956) Bull. Wld Hlth Org., 15, 1041

Department of Health and Social Security (1972) Report of the C.M.O. for the year 1971, p. 66. H.M.S.O., London

FosTER, W. D. (1970) 'The Early History of Scientific Medicine in Uganda', page 78. East African Literature Bureau, Nairobi and Kampala

and Kerchan, L. L. O. (1966) Brit. F. vener. Dis., 42, 272

GrIFFITH, H. B. (1963) Eugenics Rev., 55, 103

HeinZE, E., and GaleA, J. (1971) Course for polyvalent microscopists. W.H.O., Lagos

KING, M. (ed.) (1966) 'Medical Care in Developing Countries'. Oxford University Press, Nairobi

LoMHOLT, G. (1972) Personal communication

MASAWE, A. E. J. (1970) E. Afr. med. F., 47, 673

- and German, G. A. (1971) Afr. F. med. Sci., 3, 195

-, Nsibambi, J., and Lomholt, G. (1972) Ibid, 3, 163

Muwazi, E. M. K., Trowell, H. C. and Davies, J. N. P. (1947) E. Afr. med. F., 24, 152 and 241

OвONYO, Н. B. (1972) Personal communication

Ongom, V. L., Lwanga, V. N., Mugisha, J. K. and Mafigiri, J. T. (1971) E. Afr. med. F., 48, 367

Phillips, I., Fernandes, R., Pirani, A. A., and Wagaine, D. (1969) Ibid., 46, 38

SOMERS, K. (1972) Personal communication

UGANDA (1912) Annual Medical and Sanitary Report for 1912, page 19. Government Printer, Entebbe

- (1913) Annual Medical and Sanitary Report for 1913, Appendix III, page 78. Government Printer, Entebbe

(1921) Annual Medical and Sanitary Report for 1921, Appendix III, page 69. Government Printer, Entebbe

(1971) Report of the 1969 Population Census, the Statistics Division, Ministry of Planning and Economic Development, the Republic of Uganda

(1972) Uganda's Third Five-Year Development Plan 1971/72-75/76. Government Printers, Uganda

UNIted Nations GeNERAL Assembly Resolution 2768 (XXVI) of November 18, 1971

Changements dans l'organisation des services des maladies vénériennes et des tréponématoses en Ouganda

SOMMAIRE

C'est au début du $\mathrm{XX}^{\circ}$ siècle que commença l'organisation 
des services médicaux en Ouganda. Dans certaines parties du pays, cette organisation fut instituée principalement pour traiter les maladies vénériennes et forma la base du développement futur des services médicaux généraux.

On ne dispose pas de chiffres sûrs concernant l'incidence des maladies vénériennes partout dans le pays, mais il est évident que presque tous les types des maladies sexuellement transmises sont très communs.

L'Ouganda a maintenant un réseau largement étendu de centres de santé ruraux et de dispensaires munis d'auxiliaires médicaux qui touchent à peu près 90 pour cent de la population. Les services scientifiques de vénéréologie ne sont disponibles que dans peu de centres où, cependant, quelques recherches utiles ont pu être réalisées.

On se trouve devant plusieurs problèmes plus importants que les maladies vénériennes, qui réclament hommes, argent, équipements. Les possibilités d'améliorer les services anti-vénériens dans le cadre actuel sont discutées et l'on considère que les maladies vénériennes, en tant que problème sanitaire, doivent être portées à un niveau de priorité plus élevé. 